
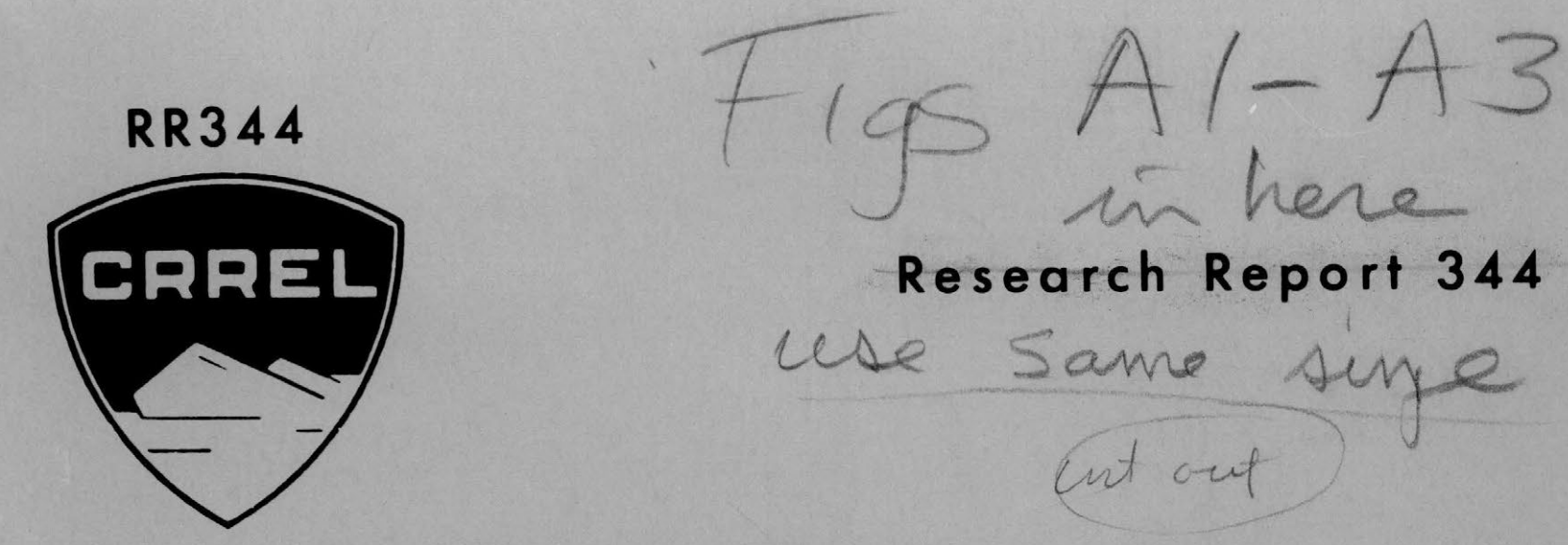

Research Report 344

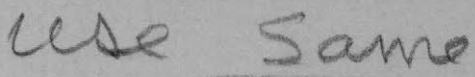

\title{
THE CLASSIFICATION AND
}

GEOMORPHIC IMPLICATIONS OF THAW LAKES

ON THE ARCTIC COASTAL PLAIN, ALASKA

\author{
P.V. Sellmann, J. Brown, R.I. Lewellen, \\ H. McKim and C. Merry
}

December 1975

Prepared for

RESEARCH AND DEVELOPMENT OFFICE

OFFICE, CHIEF OF ENGINEERS

By

CORPS OF ENGINEERS, U.S. ARMY

COLD REGIONS RESEARCH AND ENGINEERING LABORATORY

HANOVER, NEW HAMPSHIRE 


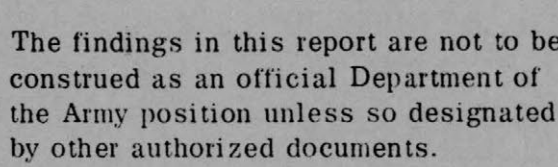




\begin{tabular}{|c|c|}
\hline REPORT DOCUMENTATION PAGE & $\begin{array}{l}\text { READ INSTRUCTIONS } \\
\text { BEFORE COMPLETING FORM }\end{array}$ \\
\hline $\begin{array}{l}\text { 1. REPORT NUMBER } \\
\text { Research Report } 344\end{array}$ 2. GOVT ACCESSION NO. & 3. RECIPIEN T'S CATALOG NUMBER \\
\hline \multirow{2}{*}{$\begin{array}{l}\text { 4. TITLE (and Subtitie) } \\
\text { THE CLASSIFICATION AND GEOMORPHIC IMPLICATIONS OF } \\
\text { THAW LAKES ON THE ARCTIC COASTAL PLAIN, ALASKA }\end{array}$} & 5. TYPE OF REPORT \& PERIOD COVERED \\
\hline & 6. PERFORMING ORG. REPORT NUMBER \\
\hline $\begin{array}{l}\text { 7. AU ThoR(s) } \\
\text { P.V. Sellmann, J. Brown, R.I. Lewellen, H. McKim and C. Merry }\end{array}$ & 8. CONTRACT OR GRANT NUMBER(s) \\
\hline $\begin{array}{l}\text { 9. PERFORMING ORGANIZATION NAME AND ADDRESS } \\
\text { U.S. Army Cold Regions Research and Engineering Laboratory } \\
\text { Hanover, New Hampshire } 03755\end{array}$ & $\begin{array}{l}\text { 10. PROGRAM ELEMENT, PROJECT, TASK } \\
\text { AREA \& WORK UNIT NUMBERS } \\
\text { DA Project 4A161102B52E } \\
\text { Task 02, Work Unit } 014\end{array}$ \\
\hline 11. CONTROLLING OFFICE NAME AND ADDRESS & $\begin{array}{l}\text { 12. REPORT DATE } \\
\text { December } 1975\end{array}$ \\
\hline $\begin{array}{l}\text { Directorate of Military Construction, } \\
\text { Office, Chief of Engineers, Washington, D.C. } 20314\end{array}$ & $\begin{array}{l}\text { 13. NUMBER OF PAGES } \\
24\end{array}$ \\
\hline \multirow[t]{2}{*}{ 14. MONITORING AGENCY NAME \& ADDRESS(if different from Controlling Office) } & 15. SECURITY CLASS. (of this report) \\
\hline & $\begin{array}{l}\text { 15a. DECLASSIFICATION/DOWNGRADING } \\
\text { SCHEDULE }\end{array}$ \\
\hline
\end{tabular}

Approved for public release; distribution unlimited.

17. DISTRIBUTION STATEMENT (of the abstract entered in Block 20, if different from Report)

18. SUPPLEMENTARY NOTES

19. KEY WORDS (Continue on reverse side if necessary and identlfy by block number)

Arctic Coastal Plain, Alaska

Permafrost

Ice

Satellites (artificial)

Images

Thaw lakes

Lakes

20. ABSTRACT (Continue on reverse oide if necoseary and identify by block number)

The lakes of the Arctic Coastal Plain of northern Alaska were classified, based on size, shape, orientation and distribution, into six lake units and three nonlake units. Regional slope and relief were demonstrated to control lake size, the largest lakes occurring on the flattest, northernmost segment of the Coastal Plain. Using ERTS-1 sequential imagery and existing photography and data, lakes were grouped according to three depth ranges, $<1 \mathrm{~m}, 1-2 \mathrm{~m}$ and $>2 \mathrm{~m}$. Deepest lakes have the longest period of summer ice cover. Ice on shallow lakes melts the earliest. Maximum depths of lakes were computed based on ice volume content of the perennially frozen ground (permafrost) and these agreed with observed values and ranges. The lake classification and regional ERTS-1 coverage also appear to provide additional information on the limits of late-Pleistocene transgressions on the Coastal Plain. 


\section{PREFACE}

This report was prepared by Paul V. Sellmann, Geologist, of the Northern Engineering Research Branch, Experimental Engineering Division of the U.S. Army Cold Regions Research and Engineering Laboratory (USA CRREL), Dr. Jerry Brown, Research Soil Scientist, Earth Sciences Branch, Research Division, USA CRREL, R.I. Lewellen, Arctic Geologist (P.O. Box 1068, Littleton, Colorado 80120) and Dr. Harlan L. McKim, Soil Scientist, and Carolyn J. Merry, Geologist, Earth Sciences Branch, Research Division, USA CRREL. The study was performed under DA Project 4A161102B52E, Research in Military Engineering and Construction, Task 02, Research in Snow, Ice and Frozen Soil, Work Unit 014, Environmental Factors Influencing Expedient and Permanent Construction of Logistic Facilities and Army Operations in Cold Environments.

Technical reviewers of this report were Dr. Robert F. Black of the University of Connecticut and Richard Haugen of USA CRREL.

The contents of this report are not to be used for advertising, publication, or promotional purposes. Citation of trade names does not constitute an official endorsement or approval of such commercial products. 


\section{CONTENTS}

Abse

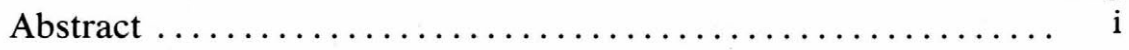

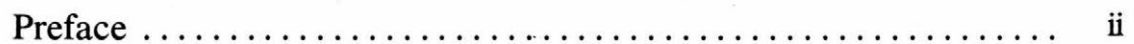

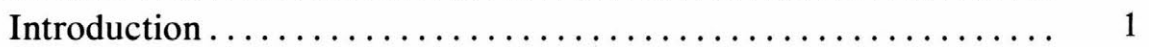

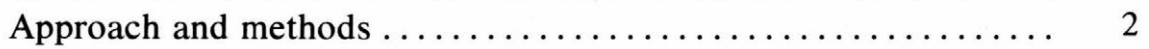

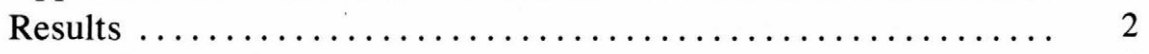

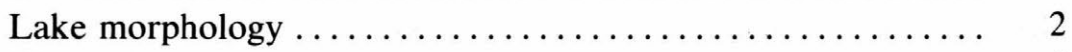

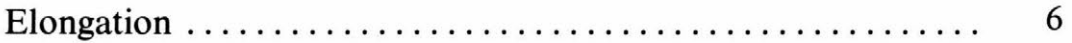

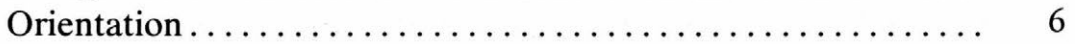

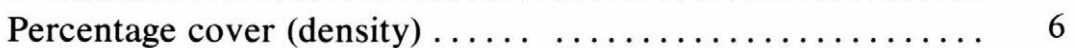

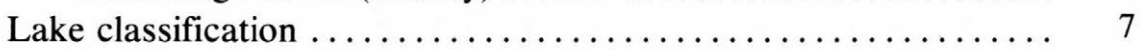

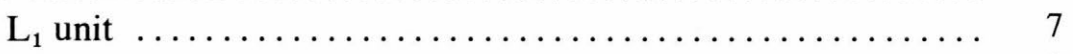

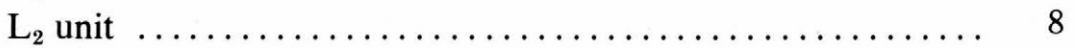

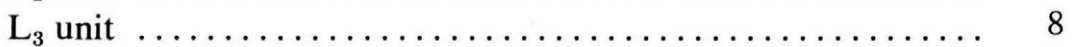

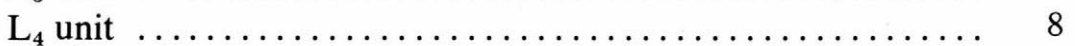

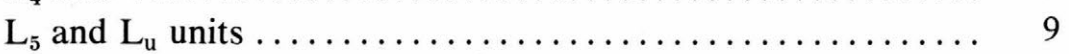

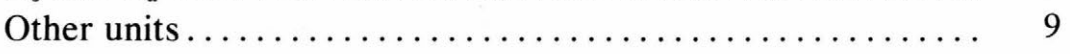

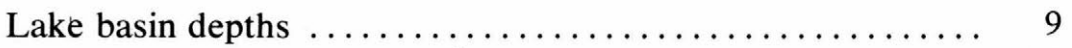

Ice volume and basin genesis $\ldots \ldots \ldots \ldots \ldots \ldots \ldots \ldots \ldots$

Geological implications ............................ 19

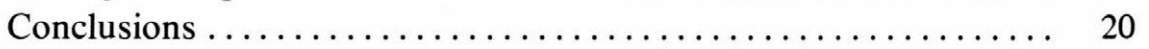

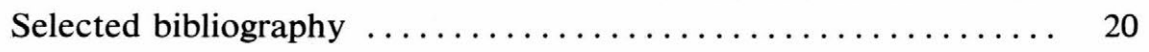


Figure

\section{ILLUSTRATIONS}

1. Maps of northern Alaska showing most of the Coastal Plain, the northern foothills and portions of the northeastern Brooks Range ............... facing pg. 2

2. Statistical characteristics of lake units $1-4 \ldots \ldots \ldots \ldots .4$

3. Lake length plotted against regional slope, with calculated curves superimposed for various scarp heights

4. A thaw lake basin containing a shallow marginal shelf and deep central basin which retains a portion of its ice cover in the deepest part of the basin ...........

5a. ERTS-1 imagery of the Teshekpuk Lake region obtained

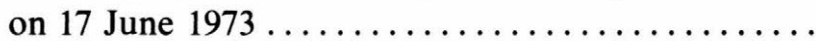

5b. ERTS-1 imagery of the same area shown in 5a obtained on 3 July $1973 \ldots \ldots \ldots \ldots \ldots \ldots \ldots \ldots \ldots \ldots \ldots \ldots$

6. ERTS-I imagery of a section of the Arctic Coastal Plain near Cape Simpson obtained on 17 June 1973 .....

7. Plot of ice volume vs depth for the CRREL auger and core samples obtained in the Barrow area ........

8. Potential thaw settlement or total basin depth vs total thaw depth for lake basins using ground ice volume

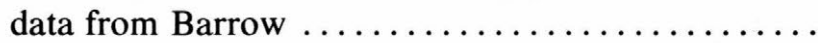

9. Barrow cross section showing "ancient" primary land surfaces, lower areas of thaw settlement associated with relatively old surfaces and a present thaw-lake surface ..............................

10. Idealized cross sections demonstrating how the interior basin of a shallow lake can deepen through thaw settlement as the lake exceeds the critical depth of 2

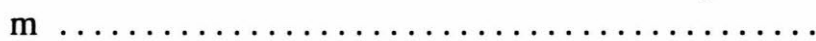

11. Northern Alaska showing limits of major transgressions proposed by previous workers $\ldots \ldots \ldots \ldots \ldots \ldots$.

\section{TABLES}

Table

I. Classification and major features of the lakes of the Alas-

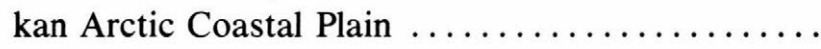




\title{
THE CLASSIFICATION AND \\ GEOMORPHIC IMPLICATIONS OF THAW LAKES \\ ON THE ARCTIC COASTAL PLAIN, ALASKA
}

\author{
P.V. Sellmann, J. Brown, R.I. Lewellen, \\ H. McKim and C. Merry
}

\section{INTRODUCTION}

A major portion of the Alaskan Arctic Coastal Plain is underlain by ice-rich marine sediments, the product of several marine transgressions and regressions. Numerous thaw lake basins of variable morphology and distribution have developed on the perennially frozen sediments (permafrost) of this low-lying plain. Most notable are the large elliptical and oriented lakes found on the northernmost part of the Coastal Plain. These lakes have long been considered a unique feature of this environment and their origin and geometry have captured the interest of many investigators (Black 1969a and b, Black and Barksdale 1949, Britton 1967, Carson and Hussey 1962, Livingstone et al. 1958). The following features make these lakes an important key to understanding the history and current processes controlling the geomorphology of this and other circumpolar permafrostdominated terrains.

1. The thaw lake cycle. The thaw lake cycle (Britton 1967), consisting of repetitive stages of lake formation and drainage, represents the primary geomorphic process that modifies this land surface. Thaw lakes are largely unstable with active erosion at their basin margins. As a result, they often coalesce and drain. Therefore, in some areas where this process is active, these lakes seldom exceed several thousand years in age (Brown 1965, Carson 1968). Recently a relatively restricted mechanism of thaw lake formation was recognized whereby sediment laden ice rafts initiated thawing of the permafrost and formation of lake basins (Ugolini 1975).

2. Topographic conditions. Topographic conditions control lake size and shape. The lower the regional slope and the local relief the greater potential for lakes of large size.

3. Erosion and local relief. Lake shape and orientation are linked to two principal controls. The major mechanism in areas of low relief and ice-rich sediment is preferential lake erosion induced by waves and currents (Carson and Hussey 1962). Another control is local relief resulting from geological structure (fault lines, basins, lineaments) or the topography associated with dunes, periglacial landscapes, and fluvial patterns (Fischer and Lathram 1973, Short and Wright 1974, Gatto and Anderson 1975).

4. Ground ice distribution. Thaw lakes influence ground ice distribution in a region. Through the erosional process and subsequent freezeback of lake sediments, thaw lakes control and tend to reduce the amount and type of near-surface ground ice and consequently the surface relef (Hussey and Michelson 1966).

5. Basin geometry. In general, lake depth is fairly uniform and is usually less than $2 \mathrm{~m}$. These lakes commonly freeze to the bottom. The lakes with some persistent ice in July generally correlate with the deeper lakes $(>2 \mathrm{~m})$ that usually do not freeze to the bottom (Brewer 1958). Lake depth is related to ground ice volume, local relief, and basin age. Many lakes have a similar basin geometry with a shallow marginal shelf. The deepest central part of the basin is usually elongate (Black and Barksdale 1949).

Lake depth determines: 1) the feasibility of using the lakes for winter water supply, 2) the biological resources associated with them, and 3) the influence of the lakes on the thickness of the thaw zone beneath and adjacent to the basins. Only the lakes that do not freeze to the bottom are useful for water supplies and contain overwintering fish populations. The depth to permafrost beneath a lake is closely related to the depth of water. 


\section{APPROACH AND METHODS}

Earlier studies of lake distribution and morphology have been based on topographic maps, conventional aerial photography, field studies, isotopic dating and comparison with other coastal areas. With the advent of high quality, summer Earth Resources Technology Satellite (ERTS-1) imagery, ${ }^{*}$ it was possible to view the regional patterns of Alaskan Coastal Plain lakes at a scale which provides simultaneous examination of lake morphology, distribution and sequential changes in ice cover. Analyses of sequential ice cover changes proved to serve as a valuable indicator of water depth. In addition, landwater area data previously available on the protracted (BLM) survey maps** have been computer digitized and the results computed and summarized at the township level. This information, in combination with ERTS-1 imagery and our familiarity with the field conditions and genetic processes, permits us to offer additional information on the occurrence and distribution of arctic thaw lakes, and their geomorphic and historical significance. Our approach was both a qualitative and quantitative assessment of lake morphology and related depth parameters.

A lake classification was developed which categorized the lakes based on basin morphology and distribution patterns. An ERTS-1 mosaic at a scale of 1:500,000 (Fig. 1b) was compiled using 1973 summer imagery (Multispectral Scanner System; MSS band 7, , 0.8-1.1 $\mu \mathrm{m}$ ) and provided the working base for this study. The parameters considered in the classification include size, axis orientation, degree of basin development, and lake density. The initial grouping was based on visual contrasts and patterns seen on the mosaic (Table I). Measurements, from standard USGS topographic maps (1:250,000 scale) of over 1500 lakes for dimensions and basin orientations, provided a quantitative basis for the classification (Fig. 2) and confirmed the more subjective grouping established by visual comparison from the ERTS-1 mosaic. All lakes with major axes $0.50 \mathrm{~km}$ or larger were measured. Measurements of the length of major and minor axes and the bearing of major axes were obtained from the USGS topographic maps instead of the ERTS-1 imagery for several reasons: 1) the maps provided a uniform basis for determining the shape or limits of the lake basins which the ERTS-1 scale and sequential images did not provide; 2) the resolution of the maps is better than the ERTS-1 imagery for measurements since they were constructed from high resolution aerial photographs of larger scales than ERTS-1;3) the maps provided coverage of areas that were partially or completely cloud covered on the ERTS-1 summer mosaic. The tabulated and plotted data (Fig. 2) were developed from selected portions of each lake unit and covered approximately $15 \%$ of the entire Coastal Plain. The number of observations made to establish these values in each lake unit is also indicated in Figure 2.

\section{RESULTS}

\section{Lake morphology}

Size. Although lake size varies greatly across the Alaskan Arctic Coastal Plain, a subdivision based on size was feasible (Table I) using three classes: large, intermediate, and small. Lake size is controlled or influenced by ground ice volume, local and regional relief, and age. The amount of ground ice is related to the depositional and freezing histories and the texture of the material in any specific area, finer textures yielding large quantities of ground ice. The largest thaw lakes would be expected on flat-lying surfaces of fine-grained sediment which contain large amounts of ground ice and where lake expansion is unconstrained by local relief.

* The imagery used for this study was obtained from NASA. as part of CRREL contract S-70253-AG ERTS-1

Data User Investigation of Arctic and Subarctic Environmental Analysis Utilizing ERTS-I Imagery; D.M. Anderson, principal investigator (DE 329). The ERTS satellite has subsequently been renamed LANDSAT.

** On file in the Anchorage office of the Bureau of Land Management. 
Table I. Classification and major features of the lakes of the Alaskan Arctic Coastal Plain.

\begin{tabular}{|c|c|c|c|c|c|}
\hline Unit & Size & $\begin{array}{l}\text { Development of } \\
\text { elongage axis }\end{array}$ & $\begin{array}{l}\text { Orientation of } \\
\text { elongate axis }\end{array}$ & $\begin{array}{l}\text { Lake density } \\
(\% \text { water coverage })\end{array}$ & $\begin{array}{l}\text { Controlling para. } \\
\text { meters and comments }\end{array}$ \\
\hline $\mathrm{L}_{1}$ & Large & Well-developed & Strong & Very dense & $\begin{array}{l}\text { Limited control; low local and } \\
\text { regional relief. Found on outer } \\
\text { coastal plain. }\end{array}$ \\
\hline $\mathrm{L}_{1-\mathrm{a}}$ & Large & Poor & None & Very dense & \\
\hline $\mathrm{L}_{2}$ & Large to intermediate & Moderate to well-developed & Strong to preferred* & Dense & $\begin{array}{l}\text { Local and regional relief, sediment } \\
\text { type and ground ice volume. }\end{array}$ \\
\hline $\mathrm{L}_{2-\mathrm{a}}$ & Intermediate & Moderate to well-developed & Strong & Very dense $>\left(L_{2}\right)$ & \\
\hline $\mathrm{L}_{2-\mathrm{b}}$ & Intermediate & Moderate to well-developed & Preferred & Dense $<\left(\mathrm{L}_{2}\right)$ & $\begin{array}{l}\text { High local and regional relief. } \\
\text { Found on higher relief inner } \\
\text { coastal plain margin. }\end{array}$ \\
\hline $\mathbf{L}_{3}$ & Small & Moderate & Strong & Very dense & High regional relief. \\
\hline $\mathrm{L}_{3-\mathrm{a}}$ & Small & Moderate to poor & Preferred & Low density & More drained basins than in $\mathrm{L}_{3}$. \\
\hline $\mathrm{L}_{4}$ & Intermediate & Moderate to poor & Preferred to poor & Dense to low density & $\begin{array}{l}\text { High local relief and some struc- } \\
\text { tural control. }\end{array}$ \\
\hline $\mathrm{L}_{4-\mathrm{a}}$ & Intermediate to small & Poor & None & Dense to low density & Indication of structural control. \\
\hline $\mathrm{L}_{5}$ & Small to intermediate & Poor to none & Poor to none & Dense to low density & \\
\hline $\mathrm{L}_{\mathrm{U}}$ & Intermediate to small & Poor to none & Poor to none & Low density & $\begin{array}{l}\text { Many drained lakes, found on in- } \\
\text { ner coastal plain margins. }\end{array}$ \\
\hline
\end{tabular}

* Preferred orientation implies a high degree of orientation of the lakes' long axes, with most of the axes within a $20^{\circ}$ grouping.

Other areas in which thaw lake development is not a dominant surface process:

F/L Fluvial/Lacustrine Low, lake-covered floodplains, on which lake geometry has been controlled by stream processes.

C/A Colluvial/Alluvial Commonly lake-free surfaces sloping to the coast or valley bottoms.

A Alluvial Stream valleys of major streams. 


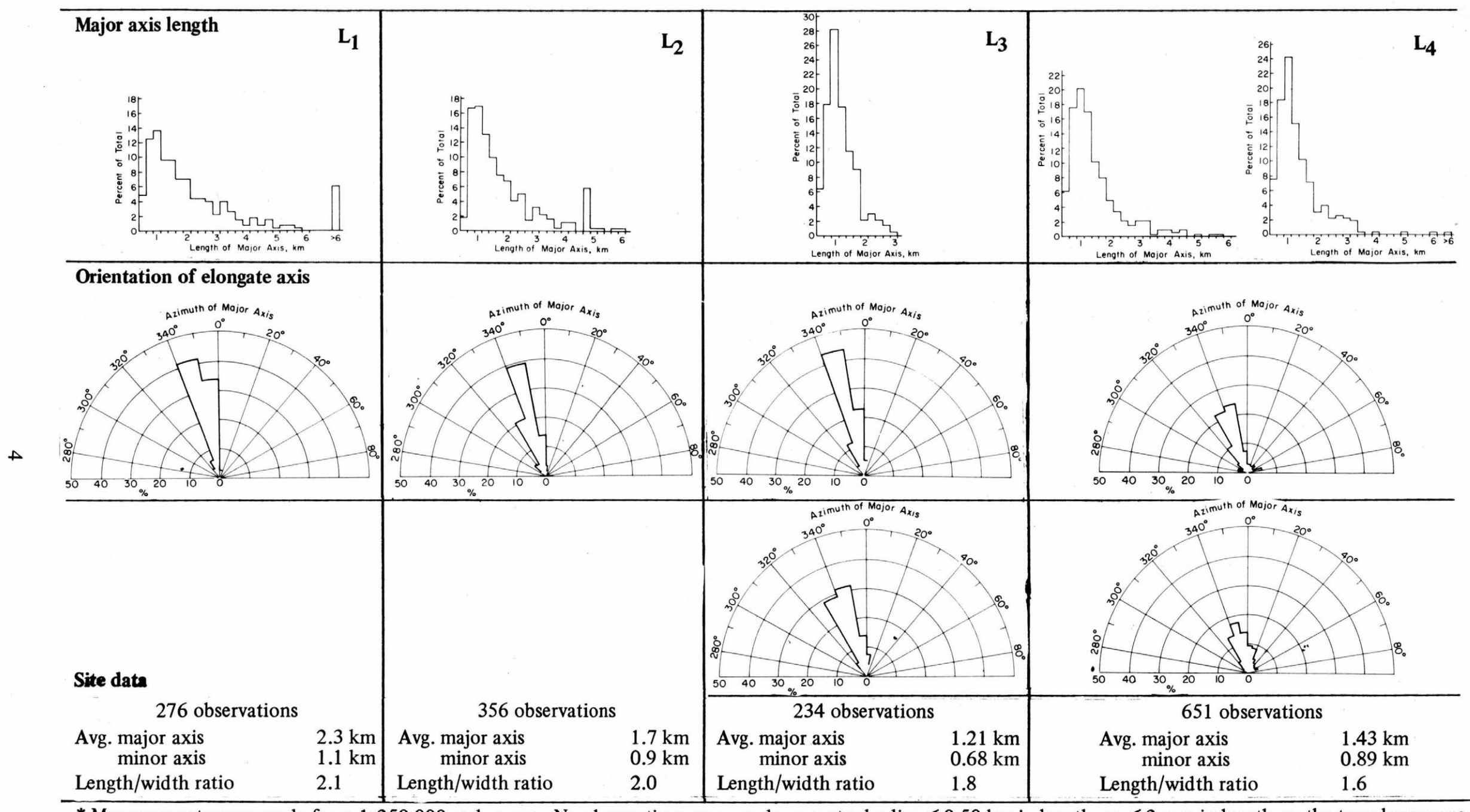

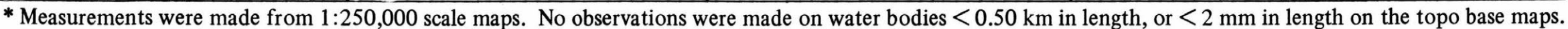

Therefore no information for lakes with major axis $<0.5 \mathrm{~km}$ in length is shown on the above histograms.

Figure 2. Statistical characteristics of lake units 1-4. 
The largest lakes occur on the outer Coastal Plain margin in the $L_{1}$ unit and exceed $6 \mathrm{~km}$ in length. This is an area of low regional and minimum local relief as compared to the other parts of the Coastal Plain. This area also consists of fine-grained marine sediments which, based on experience at Barrow (Brown and Sellmann 1973), have a high ground ice volume. Since the largest lakes occur on the lowest relief portion of the Coastal Plain (in the Teshekpuk Lake area) and the smallest lakes occur in the $\mathrm{L}_{3}$ unit (which contains surfaces with greater regional relief) an attempt was made to test the hypothesis that there is a maximum lake size for any given regional slope. A simple step approach superimposed on the regional slope was used. This approach appears valid since the preferred orientation, or maximum length, of the lakes is parallel to the slope of most surfaces. The only assumptions required for this approach were estimates of lake scarp heights commonly found on the Coastal Plain. The estimated scarp heights used were 1, 3 and $6 \mathrm{~m}$. These values limit lake length for any given regional slope. The limit, being the contact of lake ends as the lakes increase in length, is simply expressed as

$$
L_{\max }=h \cot \alpha
$$

where $L_{\max }$ is maximum lake length in meters, $h$ is lake scarp height in meters, and cot $\alpha$ is the cotangent of the regional slope angle.

Regional slopes were measured and maximum lake lengths on these slopes were plotted on both logarithmic and arithmetic graphs. The calculated relationships between slope and size are shown on the arithmetic plot for the various scarp heights mentioned in Figure 3.

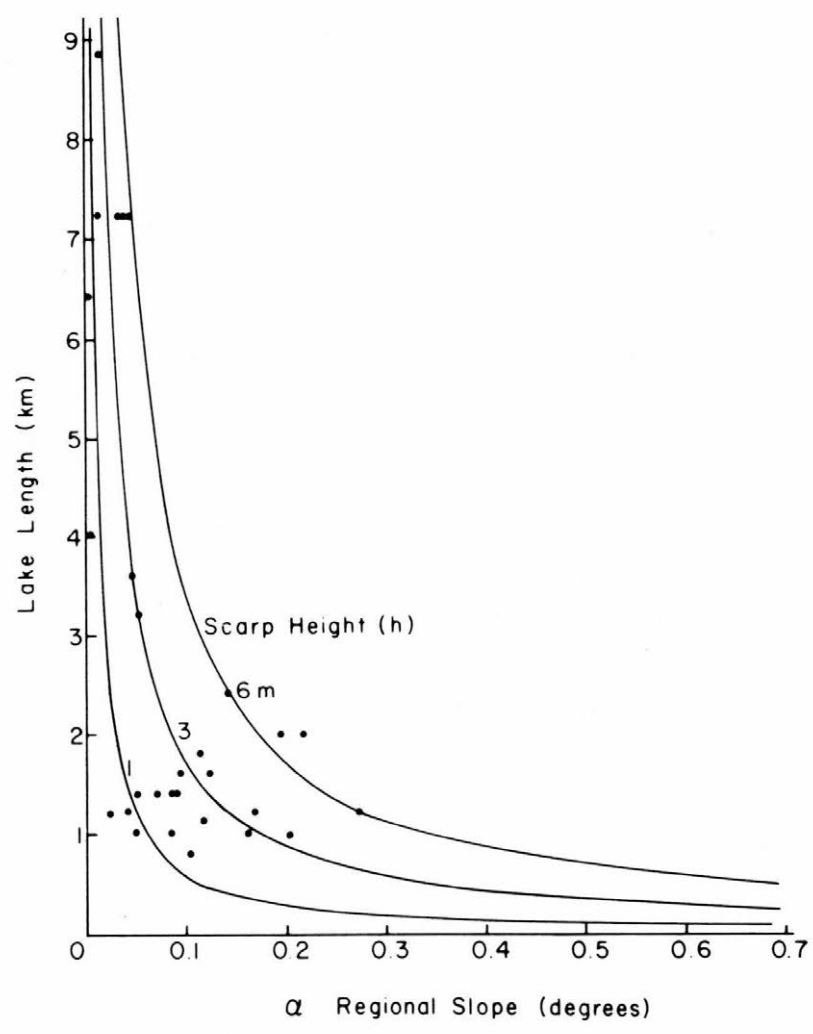

Figure 3. Lake length plotted against regional slope, with calculated curves superimposed for various scarp heights. 
The measured regional slope-lake length data taken from standard USGS topographic maps (1:250,000 scale) cluster in the range of the scarp heights selected. The arithmetic plot implies that regional slope has a strong control on the potential development of large lakes. The lakes longer than $5 \mathrm{~km}$ can only occur in extremely low relief areas of less than $0.1^{\circ}$, and as the slope decreases from this value, lake length could theoretically approach infinity. This plot also indicates that at low regional slope angles $\left(\geq 0.7^{\circ}\right)$, lakes longer than $0.5 \mathrm{~km}$ should be rare. It therefore appears that the large numbers or clusters of lakes that are apparent on 1:250,000 scale maps and ERTS-1 imagery are restricted to surfaces with very low regional relief. In areas where there is little local relief, regional relief can have a major control on lake size.

\section{Elongation}

Another common feature of the Coastal Plain lakes is their development of an elongate axis. This is made more noticeable since most of these elongated axes also have the same preferred orientation. The degree of development of elongate axes varies usually on a regional scale. Based on visual comparison, the variations were divided into four groups: well-developed, moderately-developed, poorly-developed, and undeveloped elongate axes. The measured values of both major and minor axes and the resulting length/width ratios provide a check on the above qualitative subdivision of these parameters. The average length/width ratio for the unit with the most elongate or "well developed" elongation was 2.1 and the "moderate to poor" unit had an average length/width ratio of 1.6 (Table I and Figure 2). The potential for axis elongation appears to be strongly controlled by material type and local relief.

\section{Orientation}

In this arctic coastal setting orientation is closely related to the degree of axis elongation, since the wind-induced erosional processes which encourage elongation and orientation are the same. It has been demonstrated by use of aerial photographs taken over a 20-year period that present-day erosion is occurring at the lake extremes (Brown 1970, Lewellen 1972). These observations confirm Carson's observations that elongation occurs at the end of lakes, partially due to erosion produced by wind generated waves, currents and higher water temperatures. The degree of orientation for classification purposes was divided into four groups: strong, preferred, poor, and no orientation.

All but one of the main lake units demonstrate strong or preferred orientation. The control of orientation is much the same as for elongation. The lack of orientation can generally be related to shallow overburden leading to subsurface control or surface topographic features, such as dunes. Rose diagrams of long axis orientation show the patterns for the various classes (Fig. 2).

\section{Percentage cover (density)}

The estimate of lake coverage was initially based on a visual comparison, subsequently quantified and contoured based on percentages of water-land derived from the BLM protracted survey maps (Fig. 1c). These values were derived from acreage values for water and land at the section level for the area north of the Umiat Meridian. A computer program was employed to calculate the percentage of water per section and make summations compiled at the township level. Since we were only interested in the fresh water on land surfaces, townships with saline lagoons, bays, and other coastal water features were 
rejected in the computer summations. The final township values were manually transferred to the township base map and contoured. Examination of Figure 1c indicates that the values for total area covered by lakes are lower than might be anticipated from a visual inspection of maps, aerial observations and photographs. For example, Hussey and Michelson (1966) estimated that 50-75\% of the Coastal Plain was covered either by lakes or by marshes that occupy low areas or former lake basins. However, this study showed that only very few areas (not exceeding three townships in size) have lakes covering more than $40 \%$ of their surface, and these areas amount to only about $1 \%$ of the total area contoured in Figure 1c (although marshes and drained lake basins were not included in these computations). Approximately only $22 \%$ of the region studied has lake coverage greater than 20\%. This area lies on the outer Coastal Plain and is characterized by surfaces which have not been modified by fluvial processes. The wide, alluvial surfaces have a lake coverage of commonly less than $20 \%$, which is less than adjacent Coastal Plain areas.

The larger percentages of lake coverage are found on areas of lowest relief on the youngest seaward part of the Coastal Plain. As the regional slope increases, the percentages of water coverage decrease. This is particularly noticeable on the high-relief, inner margins of the Coastal Plain where values are below 5\%. Some small areas of larger percentages are localized on small plateaus or low relief plains isolated in areas of higher relief (Fig. 1c).

In the higher relief, western section of the Coastal Plain this general trend is again borne out where low percentages of water cover are found, as compared with the higher percentages found on the low relief, central part of the plain.

In some areas slope may only be a secondary factor controlling the amount of land covered by lakes, with such factors as the thickness of sediment over bedrock being more critical. Although many areas on the Coastal Plain have very small contrasts between slopes, the average slope is still large enough to cause major differences in lake morphology. Slope is assumed to be the primary controlling variable in differentiating units $\mathrm{L}_{1}$ and $\mathrm{L}_{3}$.

\section{LAKE CLASSIFICATION}

Based on the parameters of size, development and orientation of elongate axis, and percentage coverage already described, the lakes were grouped and mapped into six lake units and three nonlake units (Table I). Within the lake units, the first four $\left(\mathrm{L}_{1}-\mathrm{L}_{4}\right)$ are the most common and well-defined. The remaining two $\left(\mathrm{L}_{5} \& \mathrm{~L}_{\mathrm{u}}\right)$ are more general and accommodate the few departures from the main units. Several lake units contain subordinate groups, which are denoted by a letter subscript, and represent departure from characteristics within the main unit.

\section{$\mathbf{L}_{1}$ unit}

The $\mathrm{L}_{1}$ unit is characterized by large lakes which cover the low-lying, seaward portion of the Coastal Plain. The combination of low regional and local relief and the properties of the sediments are thought to be responsible for the lake basin characteristics. The lakes are most distinctive because of their large size, elongated shape, and dominant long-axis orientation. The unique appearance of the lakes in this unit, in contrast to those in the remainder of the region, suggested to early workers that the history of this area was different than that of adjacent areas (O'Sullivan 1961). O'Sullivan considered this unit as the youngest part of the Coastal Plain, which must have been formed or modified by a marine transgression in late Sangamon or mid-Wisconsin time. 
Approximately $75 \%$ of the lakes in this unit have their elongate axes oriented between $340^{\circ}$ and $360^{\circ}$. This is also the only unit containing lakes that significantly exceed $6 \mathrm{~km}$ in length, and this unit has the least number of lakes in the smaller size range $(1 \mathrm{~km})$. The lakes have the largest length/width ratio, supporting the visual impression that these basins are more elongated than lakes in other units.

A subordinate group $\mathrm{L}_{1-\mathrm{a}}$ was established for a small part of the study area that contained large lakes that departed from the main unit. Lakes in group $\mathrm{L}_{1-\mathrm{a}}$ have poor development of elongate axes and consequently no definite orientation.

$\mathbf{L}_{2}$ unit

The $\mathrm{L}_{2}$ unit includes lakes that are large to intermediate in size. None of these lakes exceed $6 \mathrm{~km}$ in length, and the number of smaller lakes in the 1-km size range is greater than in $L_{1}$. The basins in this unit are more elongated than those in all of the other units except $\mathrm{L}_{1}$. The orientation of the long axes of the basins shows the same general strong trend as lakes in the first unit, although there is slightly more scatter around this dominant orientation.

Two subordinate groups $\mathrm{L}_{2-\mathrm{a}}$ and $\mathrm{L}_{2-\mathrm{b}}$ were established in this unit to cover areas in which lakes were smaller, less dense, or less oriented than in the major unit. The $\mathrm{L}_{2-\mathrm{b}}$ lakes were primarily found on the higher relief inner margin of the Coastal Plain, and lacked strong orientation.

\section{$\mathbf{L}_{3}$ unit}

The $\mathrm{L}_{3}$ unit was established to include those areas covered with small lakes that have strong-preferred orientation. The histogram of major axis length for this unit shows an increase in the number of basins in the 1-km size range and no lakes with axes larger than 3 $\mathrm{km}$. The rose diagrams of axes orientation for $\mathrm{L}_{3}$ lakes show the same general trend as in the previous units.

One subordinate group $\mathrm{L}_{3-\mathrm{a}}$ was recognized for small areas which had less welldeveloped orientation and lower density than the primary unit. This unit also appeared to contain more drained lakes.

\section{$\mathbf{L}_{4}$ unit}

The $\mathrm{L}_{4}$ unit provides a grouping for the lake basins that do not have the well-developed orientation and elongation common to the other units. These lakes appear to have some control, such as local relief, influencing their development. In some cases this influence is most likely related to surface features such as dunes or structural control in areas of thin surface sediment. The lengths of major axes of these lakes group primarily in the 1-km size range, and compared to the other lake units, this unit falls between $\mathrm{L}_{2}$ and $\mathrm{L}_{3}$. There are also few large lakes, only a very small percentage of which exceed $6 \mathrm{~km}$ in length, and compared to $\mathrm{L}_{1}$ and $\mathrm{L}_{2}$, this unit contains a smaller percentage in the 3 to $6 \mathrm{~km}$ size range. The rose diagrams for this unit show the pronounced deviation from the common elongation and orientation common to the previous three units.

An additional subunit $\mathrm{L}_{4-\mathrm{a}}$ was established to accommodate lakes with no orientation and, in some cases, smaller size than the main unit. Although not shown on Figure 1 because of size limitations, this unit is the common one on the eastern section of the Coastal Plain in the vicinity of Barter Island. 
No statistical sampling was made of the lakes in these units. These lakes often lack preferred orientation and elongation of their basins and they commonly are of low density. They often occur on the inner margins of the Coastal Plain in areas of high relief. Apparently the sediments and/or the relief found in these areas have an overriding control on their shape, which departs from the characteristics seen in other parts of the Coastal Plain.

\section{Other units}

The remaining units primarily contain nonlake surfaces or sections of the Coastal Plain on which lake geometry has been modified by more dominating processes, such as fluvial, colluvial, and alluvial activities.

Alluvial unit (A). The alluvial areas are usually associated with current river systems, particularly with recent flood plains, and form belts or strips that cut across the lake units. Several of the A unit areas are rather extensive.

Fluvial-lacustrine unit $(F / L)$. This unit includes areas of low relief which are associated with flood plains and terraces in which stream channel development and ground conditions have influenced potential lake development. It is most common on the lower reaches of the more major rivers and streams that flow across the flat low-lying portion of the Coastal Plain. Lakes in this unit commonly have a truncated appearance and some basins fill old meanders.

Colluvial/alluvial unit $(C / A)$. This unit was developed to contain what appeared to be more featureless sloping surfaces along streams and the coastline (areas in which thaw lakes are not common) than found in other units. This unit forms bands along the slopes of more major streams, and the transitions between land surfaces are of varying elevations. The slope of these surfaces may be as low as $2^{\circ}$ to $4^{\circ}$ based on observations by Hussey and Michelson (1966).

\section{Lake basin depths}

Depth classes. As a result of the examination of the ERTS-1 imagery for development of the lake classification, additional information becomes apparent, lake depth being the most notable and significant. Earlier workers had indicated that lakes with a persistent mid- to late-summer ice cover are the deepest lakes (Brewer 1958, Black and Barksdale 1949) because they have the thickest ice mass to melt. The ERTS-1 imagery enabled us to follow progressive melting of lake ice during the late spring, and early- and mid-summer periods. Using all ERTS-1 cycles and both MSS band $5(0.6-0.7 \mu \mathrm{m})$ and band $7(0.8-1.1$ $\mu \mathrm{m})$, a fairly detailed inventory and classification of lake depths is possible. Three depth categories were delineated: 1) lakes in excess of $2 \mathrm{~m}$ which do not freeze to the bottom, 2) more shallow lakes of intermediate depth (1-2 m) that freeze to the bottom, and 3$)$ very shallow lakes and ponds $(<1 \mathrm{~m})$ some of which are basins that are seasonally filled at the time of spring runoff.

The approach used in distinguishing between the lakes in the three depth classes was based on June and July 1973 ERTS-1 imagery. The deepest lakes retain their ice cover (white on ERTS-1 band 7) for the longest period. During June and early July an open water moat is formed around the floating ice mass which corresponds to a shallow shelf, usually less than $1 \mathrm{~m}$ in depth, which surrounds the deeper central basin. The floating ice mass itself corresponds to thicker ice formed over the deeper basin. For example, a low altitude aerial oblique view of a thaw lake in early July shows a large ice mass remaining over the 
deeper central part of the basin and corresponding in shape to part of this inner basin (Fig. 4). The formation of the shallow moat around the deeper central basin can be seen when comparing Lake A on Figures 5a and b. The shallow shelf area is ice-free early in July. Comparison of the June imagery (Fig. 5a) with the July imagery (Fig. 5b) illustrates the loss in ice cover during the elapsed period.

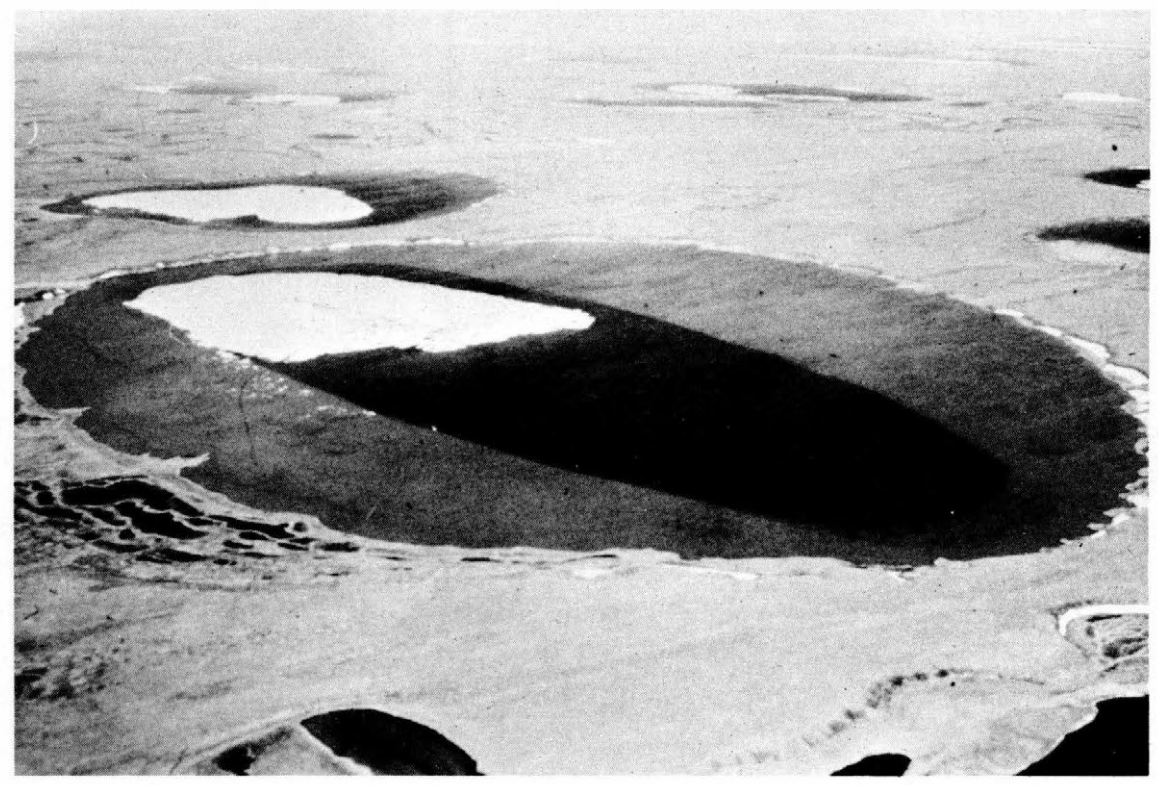

Figure 4. A thaw lake basin containing a shallow marginal shelf and deep central basin which retains a portion of its ice cover in the deepest part of the basin (photograph by R.K. Haugen, USA CRREL).

The second depth class is somewhat less obvious than the first group. This class includes lakes that have frozen to the bottom. In the "ERTS-1 MSS band 7 imagery, these lakes appear dark, suggesting no ice cover. However, this class of lakes appears white in MSS band 5. This difference is due to freestanding water on the surface of ice which is frozen to the bottom and the greater ability for water penetration with MSS band 5 imagery. A number of examples of this can be seen in the lakes adjacent to Sinclair Lake in Figure 6. A comparison of MSS bands 5 and 7 imagery of Sinclair Lake also suggests that the western margin of this lake is flooded by surface runoff. The penetration of light through water for MSS band 5 imagery has been reported to be as great as $3 \mathrm{~m}$ (Polcyn and Lyzenga 1973). Brewer (1958) also noted that the ice on shallow lakes may melt from the top without ever floating, and that this ice condition can frequently be observed during flights over the Coastal Plain in late June.

The third depth class consists of the shallow lakes that appear dark on both MSS bands 5 and 7 imagery early in the melt season. These are considered very shallow lakes $(<1 \mathrm{~m})$ from which the ice cover rapidly melts. They also may be only seasonally filled lakes that occupy old drained lake basins at time of runoff. Some of these seasonal lakes may completely drain or the water may evaporate from these marshy areas by mid-summer. Recently Sellmann et al. (1975) appear to have demonstrated the ability of side-looking airborne radar (SLAR) to differentiate arctic coastal lakes which were frozen and not frozen to the bottom. 

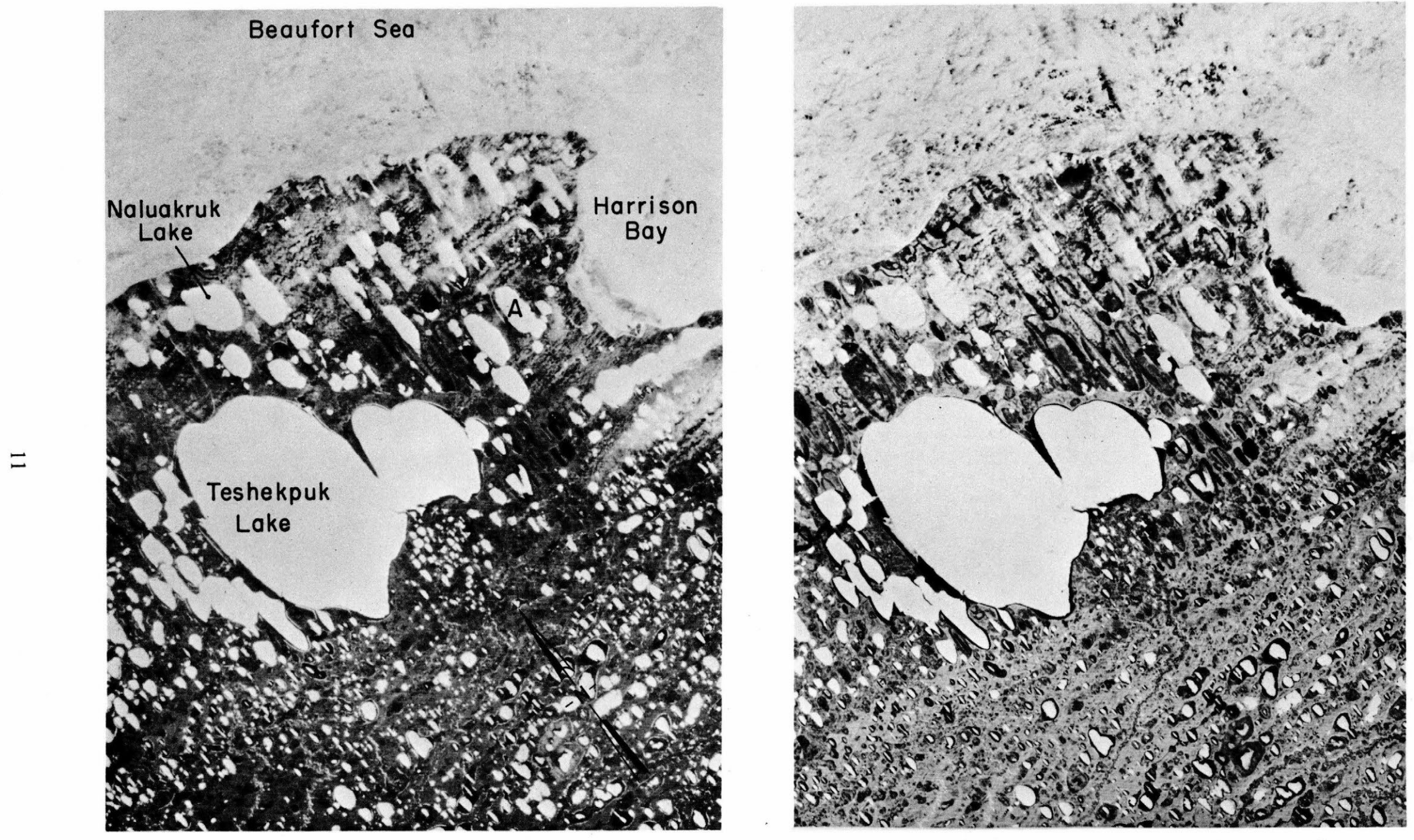

Figure 5a. ERTS-1 imagery of the Teshekpuk Lake region obtained on 17 June 1973 (NASA ID no. E-1329-21455), with band 5 on the left and band 7 on the right. Comparison of Figure $5 a$ and 5 b indicates dissipation of lake ice cover with time. 

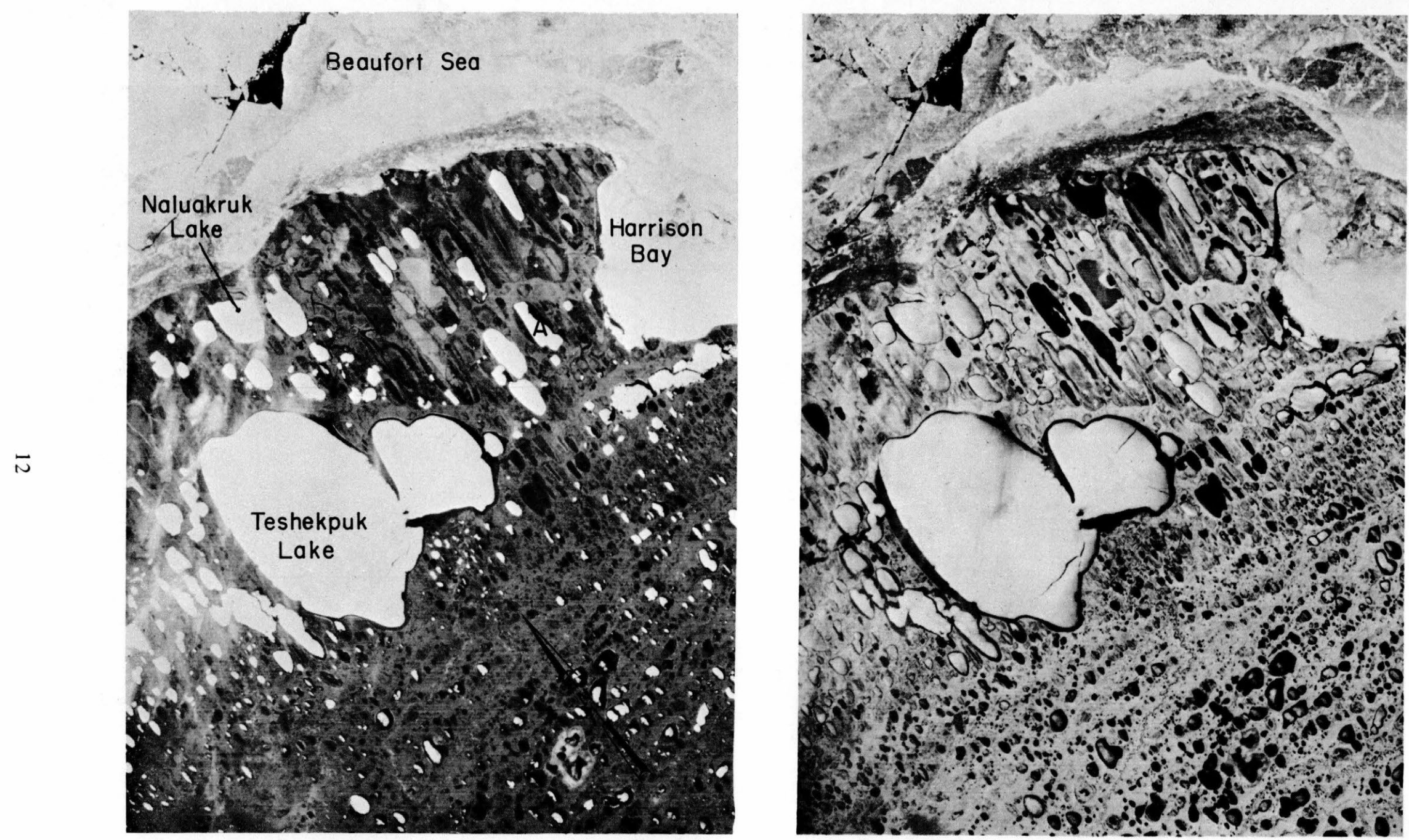

Figure 5b. ERTS-1 imagery of the same area shown in 5 a obtained on 3 July 1973 (NASA ID no. E-1345-21342), with band 5 on the left and band 7 on the right. 



Figure 6. ERTS-1 imagery of a section of the Arctic Coastal Plain near Cape Simpson obtained on 17 June 1973 (NASA ID no. E-1329-21455). Band 5 imagery is shown on the left and band 7 shown on the right for comparative purposes. Note the contrast in tone between the lakes to the southeast of Sinclair Lake. 


\section{Ice volume and basin genesis}

The depth of thaw lakes basins appears to be controlled principally by the ice volume in the original frozen sediment (Livingstone et al. 1958, Hussey and Michelson 1966). Brewer (1958) indicates that the lakes in the Barrow area fall into two depth classes: 0.6-0.9 $\mathrm{m}$ and 1.8 to $2.7 \mathrm{~m}$. These depth ranges can be considered representative of the most outer part of the Coastal Plain.

The relationship between segregated ice volume and depth was developed from both our studies in the Barrow area and from those of O'Sullivan (1966). The CRREL data are plotted in Figure 7 and are based on a composite of shallow auger holes and deeper coring (Brown 1969, Sellmann and Brown 1965, 1973). The noticeable feature of this curve is the large amount of segregated ice in the upper 3 to $5 \mathrm{~m}$. Ice volume associated with ice wedges is not included in this plot. For purposes of potential thaw settlement calculations (Fig. 8a and b) estimates of wedge ice were applied to the upper $3 \mathrm{~m}$ of ice thickness, based on 10 and $20 \%$ additional ice due to wedges. These estimates seem reasonable, based upon observed occurrences of wedges associated with polygon troughs and estimates of buried ice (UNESCO 1970).

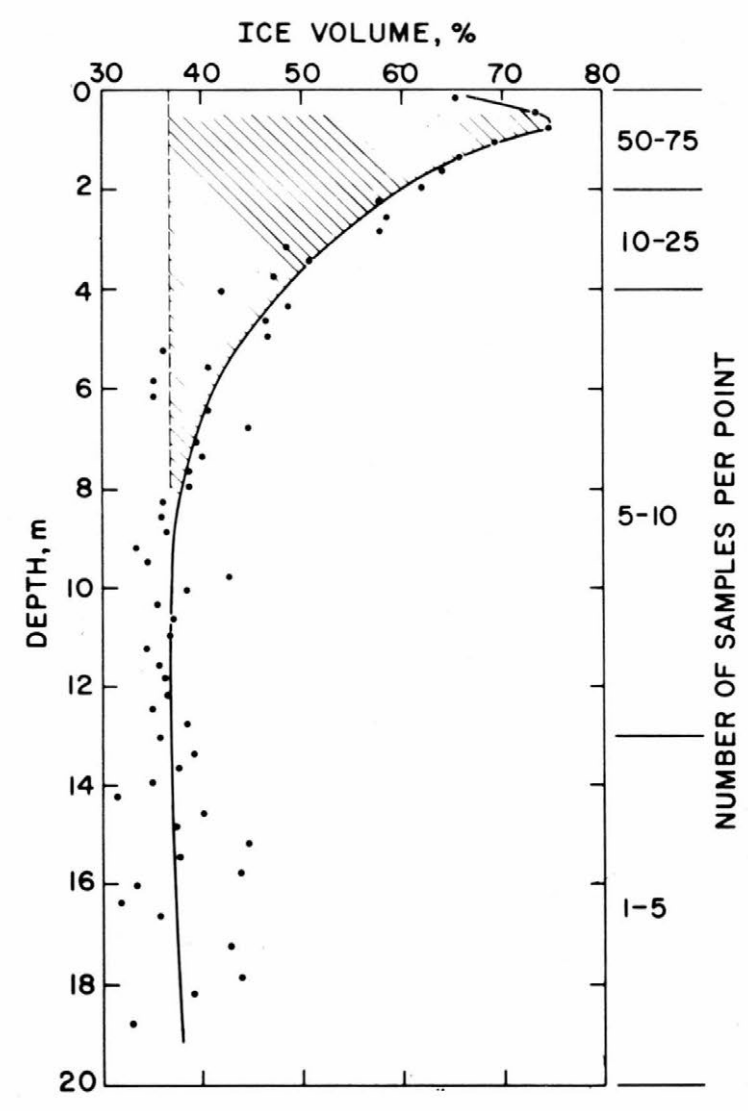

Figure 7. Plot of ice volume vs depth for the CRREL auger and core samples obtained in the Barrow area. These values are for segregated ice (pore and lens) and do not include the volume of ice associated with ice wedges, which may be as high as 10 to $20 \%$. 
The settlement for a given amount of thaw is based on the volume of ice in excess of the anticipated volume of voids formed in the resulting thawed sediment. The excess ice volume was directly equated to potential thaw settlement for 1-m increments and plotted against thaw depth. Two porosity values corresponding to a silt and a sandy silt were used for the thawed sediment. The 0.40 porosity value resulted in curves that flattened at a thaw depth of $6 \mathrm{~m}$, since at the 7-m depth the void volume exceeded the total ice volume, indicating no additional potential for settlement. The curves, based on a porosity of 0.35 , yield a small amount of excess ice at depth and a potential for small amounts of additional settlement. The real situation probably falls between these two cases.

The data indicate a noticeable decrease in ice volume with depth which is most likely characteristic for most, if not all, of the Coastal Plain for the following reasons: 1) the limited thickness of the fine-grained overburden, which has the potential for high-ice volumes, overlying low ice volume bedrock or sediments, and 2) the higher volumes of wedge ice and lens ice which are more commonly found near the surface. Massive ice can be found at greater depths under special conditions particularly under rapidly aggrading surfaces (Mackay 1972).

The control of basin depth (depth below original or primary surface to the lake bottom) on the data in Figure 8 becomes more obvious when it is appreciated that lakes less than 2 $\mathrm{m}$ in depth freeze to the bottom. In the Barrow area these shallow ponds and lakes have a summer thawed zone of between 0.3 and $0.7 \mathrm{~m}$ which refreezes annually (Brewer 1958, Coyne and Kelley 1974). Lakes deeper than $2 \mathrm{~m}$ develop a perennial thaw bulb (Lachenbruch et al. 1962). Once the higher ice zone has been thawed, the influence of the progressively deeper thaw appears to be small, since the ice volumes with depth are relatively low and thus thaw does not contribute to settlement.

In lakes $2 \mathrm{~m}$ deep, bottom temperatures are such that the freezeback potential of a $0.7-\mathrm{m}$ annual thaw zone is marginal, representing the threshold at which a permanent thaw bulb will start to form (Brewer 1958).

Depths of several lakes in the Barrow area were plotted on thaw-settlement curves (Fig. 8b). Lake depth and thaw depth is also presented in Figure 8c, with $a$ being distance from the original surface to the lake surface, $b$ representing maximum lake depth, and $c$ indicating depth of thaw under the basin. Therefore, the sum of $a$ and $b$ equals thaw settlement, and the sum of $a, b$ and $c$ equals total thaw depth. Data for lakes 1, 4, 5 and 6 were obtained from observations by Brewer (1958). Although limited, actual lake data appear to agree with the thaw-settlement data; no thaw depth data $c$ were available for lakes 5 and 6 , indicated by dashed lines across the plot (Fig. 8b).

The solid line $\mathrm{x}$ in Figure 8a indicates that shallow lakes have no potential of becoming deeper than $1.4 \mathrm{~m}(a+b)$ in terrain containing $10 \%$ by volume wedge ice and a seasonal thaw of $0.7 \mathrm{~m}$. Any additional thaw settlement, as indicated by the intersection of this line and the thaw-settlement curves, would require additional excess ice volume.

A $20 \%$ volume of wedge ice is necessary for developing basins that exceed $2 \mathrm{~m}$ depth. The deeper range of lakes $(4,5$ and 6$)$ in the Barrow area also indicates that once this $2-\mathrm{m}$ range is exceeded only minimal settlement takes place. Lake 4 , for example, had a $58-\mathrm{m}$ section with temperatures above $0^{\circ} \mathrm{C}$ below the basin and only $3.3 \mathrm{~m}(a+b)$ of settlement.

In their investigation of tundra relief features Hussey and Michelson (1966) discussed the influence of thaw consolidation on the development of relief on the Coastal Plain near Barrow. In their approach, they considered the influence of thaw lake history on the various surfaces and how it modifies ground ice volume distribution. They found that the oldest surface that has not been recently modified by thaw lakes has the greatest potential for thaw consolidation. Their grouping of the land surfaces in order of decreasing ground ice volume is as follows: initial surface, ancient drained lake basins, recent drained lake 


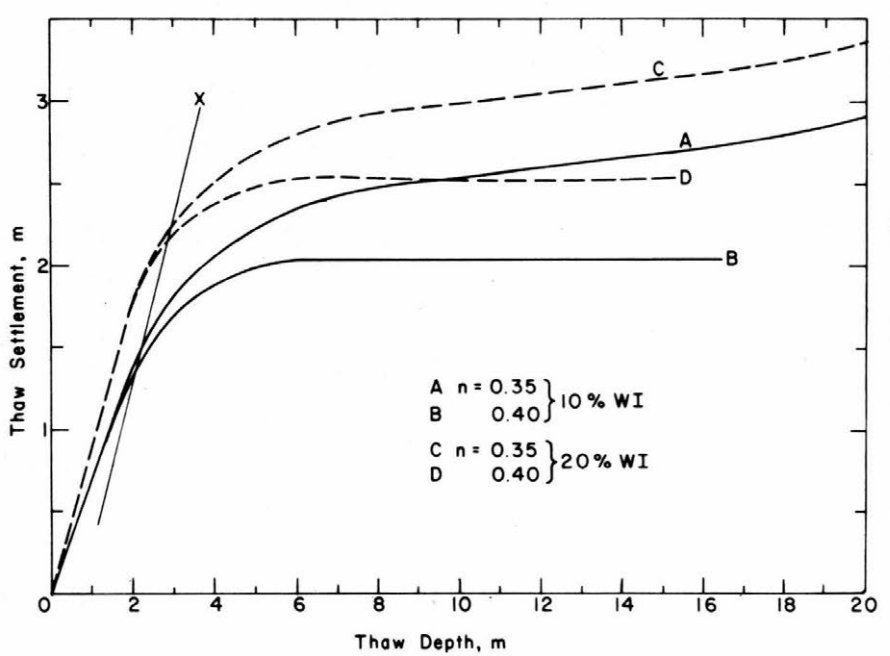

a. The solid pair of curves was obtained by using a wedge ice volume of $10 \%$ in the upper $3 \mathrm{~m}$ and porosity values for the resulting thawed sediment of 0.35 and 0.40 . The other pair is for $20 \%$ wedge ice in the upper $3 \mathrm{~m}$.
Lake Data

(m)

Settlement Thaw Depth

$\begin{array}{cccc}1 \text { a } & 0.2 & (a+b) & (a+b+c) \\ \text { b } & 0.8 & 1.0 & 1.7 \\ \text { c } & 0.7 & & \end{array}$

2 a 0.5

b 0.9

1.4

c 0.7

3 a 0.2

b 2.0

2.2

c 0.8

4 a 0.3

b 2.8

3.1

61.1

c 58.0

5 a 0.5

b $1.8 \quad 2.3$

$\begin{array}{ll}\text { c } & \\ \text { a } & 0.5\end{array}$

b 2.7

c

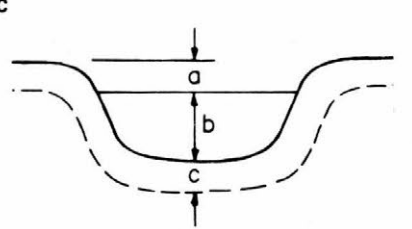

c. Sample lake data, with a being the distance from the original surface, $b$ representing maximum lake depth, and $c$ indicating depth of thaw under the basin.

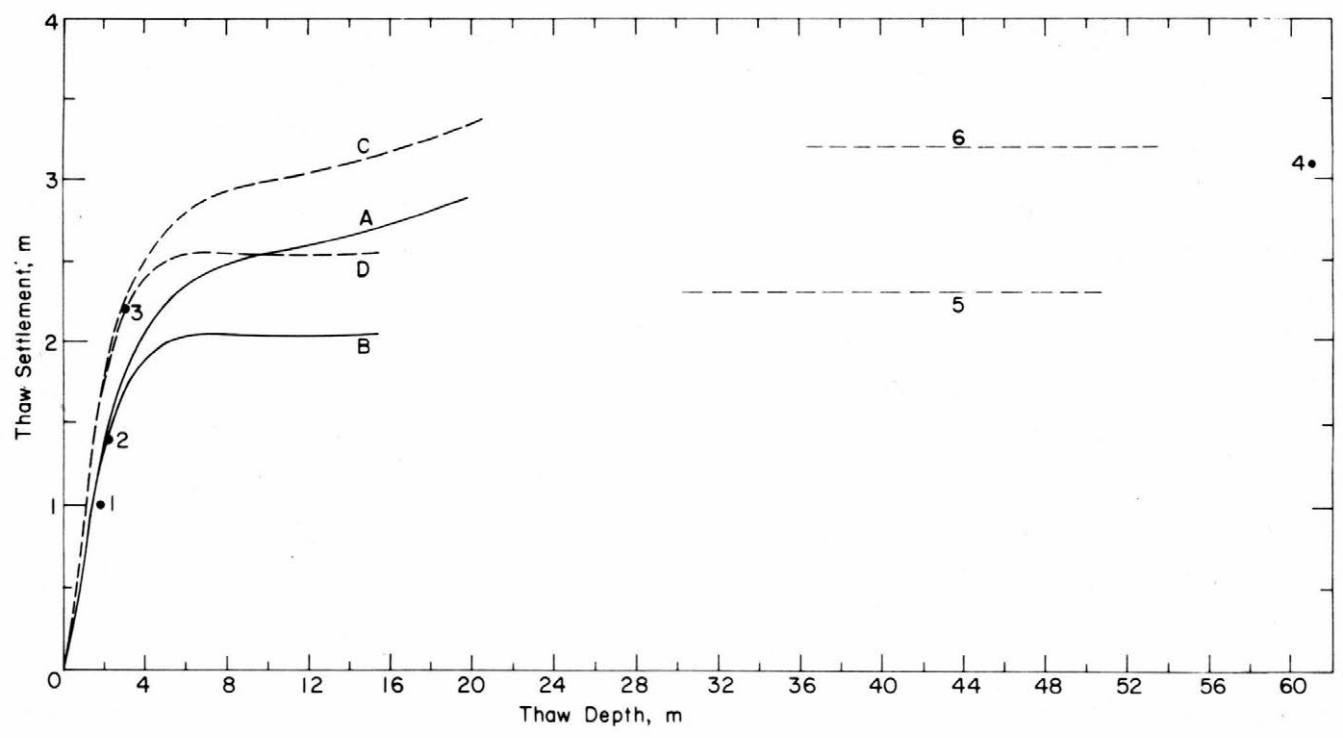

b. Lake data (from $8 a$ and $8 \mathrm{c}$ ) plotted for comparative purposes.

Figure 8. Potential thaw settlement or total basin depth vs total thaw depth for lake basins using ground ice volume data from Barrow. 


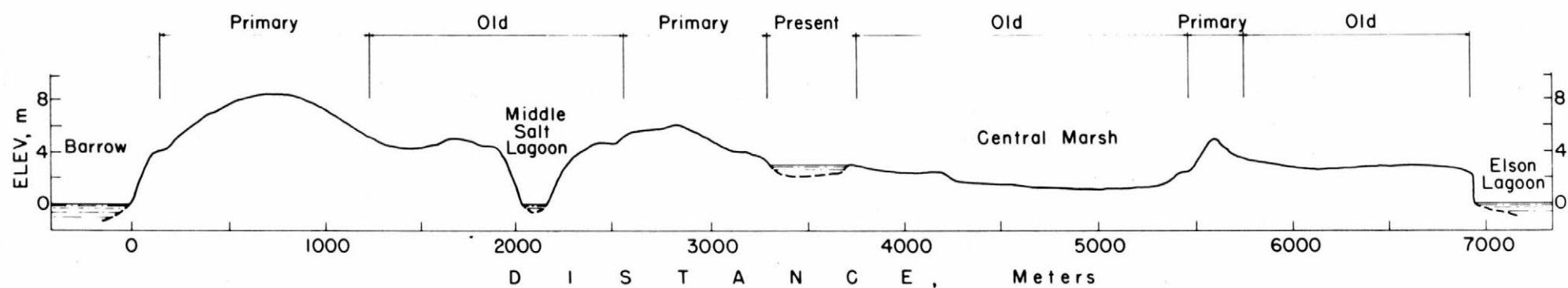

Figure 9. Barrow cross section showing "ancient" primary land surfaces, lower areas of thaw settlement associated with relatively old surfaces and a present thaw-lake surface. 
basins, and present lake areas. The ranges of settlement for these surfaces, based on limited subsurface data due to thaw of the upper $6 \mathrm{~m}$ of the permafrost, were $3.4 \mathrm{~m}, 1.2 \mathrm{~m}$, $0.7 \mathrm{~m}$, and $0.1 \mathrm{~m}$ respectively.

Our thaw settlement curves provide information to greater depth, since they are based on a large number of drill holes from all the above surfaces except present lake basins.

The thaw lake settlement process for the Barrow landscape is depicted in Figure 9, an idealized cross section between Barrow Village and Elson Lagoon. A series of lakes has occupied most of the area. The highest areas in the Barrow vicinity are considered primary or initial land surfaces (Hussey and Michelson 1966). However, small lakes have locally thawed and reworked some of this surface. This primary surface is the source of much of the ice volume data in Figure 7 to depths approaching sea level. Immediately to the east of this area, a series of old lakes has thermally eroded the original ice-rich sediments to about $5 \mathrm{~m}$ above sea level, some $3 \mathrm{~m}$ lower than the adjacent primary land surface. This amount of thaw settlement agrees with Hussey and Michelson's determinations as well as with our own thaw settlement curve. Furthermore, radiocarbon dating of a buried lacustrine peat, indicating an age of 12,160 \pm 200 years B.P. (Lewellen 1972) at $2.2 \mathrm{~m}$ above sea level, suggests the maximum period over which this process has occurred.

The basin shown in Figure 4 illustrates the characteristic shallow shelf surrounding a deeper inner basin common to some lakes in this setting. The origin of these shelves is not completely understood. Black (1969b) indicates that the shelves may have a complicated history in that portions of them may be depositional and other parts erosional. It is suggested by the authors that the shelves of some lakes may be closely linked to the thermokarst origin of these lakes, and very likely to a particular stage in their development cycle. Adequate ground ice must be available in the permafrost to provide local settlement of the basin in excess of $2 \mathrm{~m}$ upon thaw. As indicated earlier, when this critical lake depth is reached in the central part of the basin, a perennial thaw zone will develop beneath it (Fig. 10). The increasing thaw depth can result in additional settlement in the central basin if adequate ground ice is available. On shallower shelves only a seasonal thaw zone is maintained with no additional thaw settlement due to the insulating effect of accumulating sediments and shallow water. The thaw of the permafrost underlying the central basin may eventually continue toward the lake margin until most of the basin is deepened to a depth greater than $2 \mathrm{~m}$. This would represent a more mature stage in lake development in areas where subsurface conditions did not limit basin development.

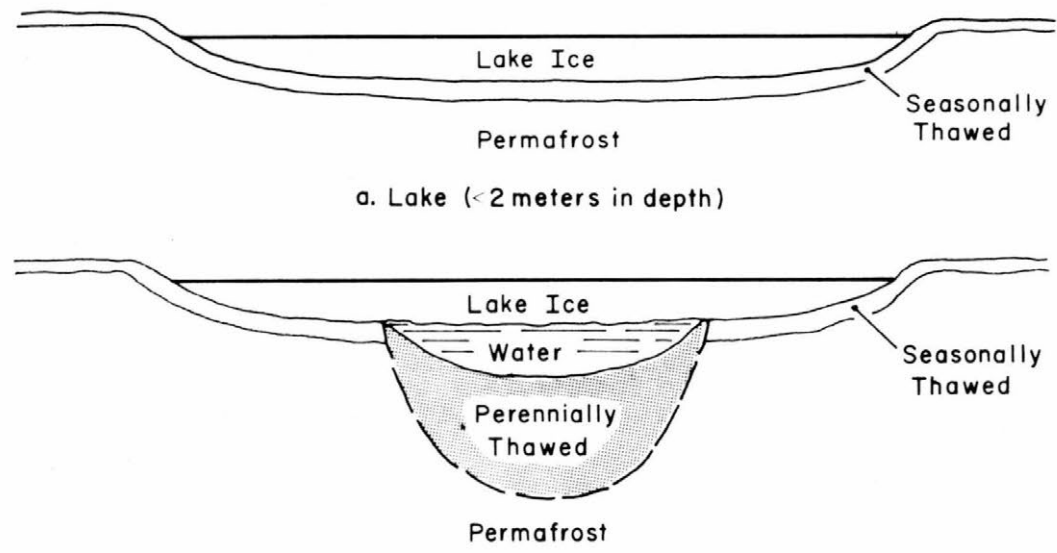

b. Central Basin ( $>2$ meters in depth)

Figure 10. Idealized cross sections demonstrating how the interior basin of a shallow lake (a) can deepen through thaw settlement as the lake exceeds the critical depth of $2 m(b)$. 


\section{GEOLOGICAL IMPLICATIONS}

The ERTS-1 imagery and its regional view of the arctic lakes established not only the influence of local and regional relief, and to a lesser degree ground conditions on lake geometry, but also provided further evidence on the historical development of the Coastal Plain. In developing the depositional history of this region, past workers have relied in part on the physical appearance of the land surface, mainly exemplified by the lake distribution patterns and topographic breaks. The positions of previously recognized strand lines are shown in Figure 11. When comparing the positions of these strand lines it can be seen that those suggested by Black (1964) and O'Sullivan (1961) are in general agreement for the last major transgression during mid- to late-Wisconsin time. This limit coincides with the surface covered by large lakes in the $\mathrm{L}_{1}$ unit. Some variation in lake types exists in this region, largely caused by disruption of lake processes by major north-flowing rivers and streams that have meandered across this flat part of the Coastal Plain following the last major transgression. For that reason, many lakes in the area were mapped in a fluvial/ lacustrine unit.

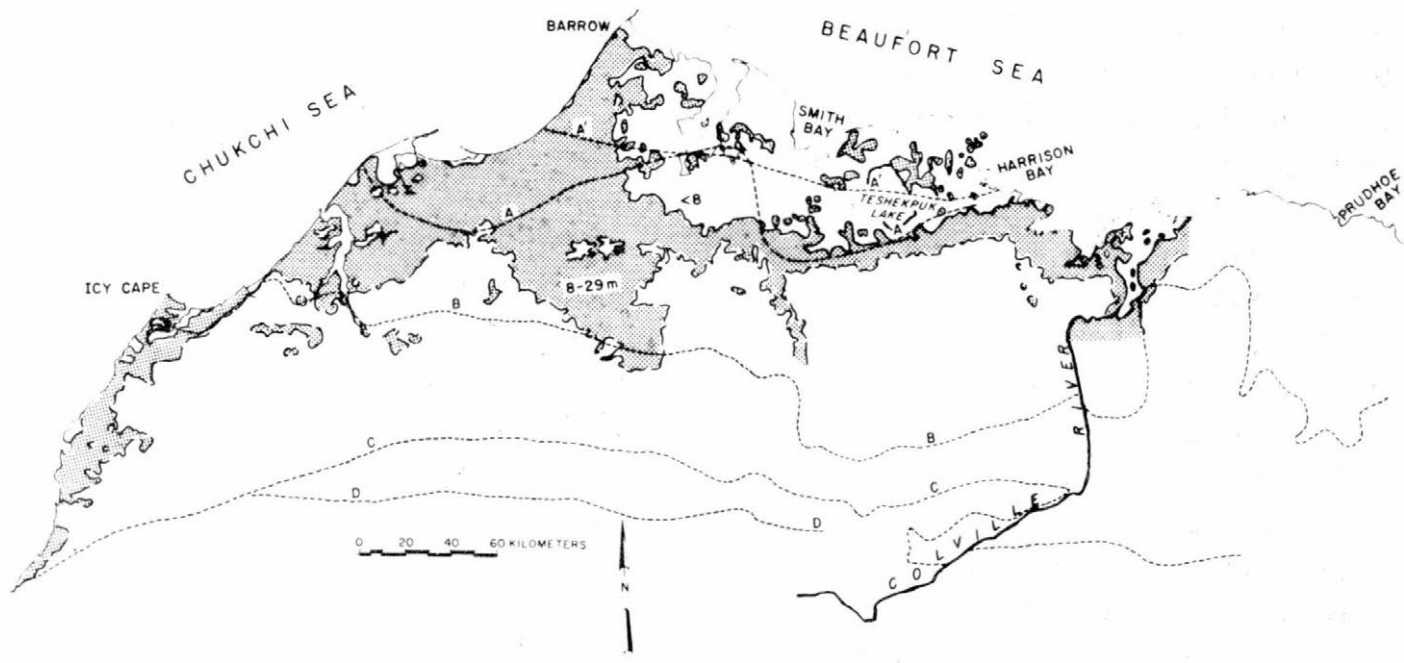

Figure 11. Northern Alaska showing limits of major transgressions proposed by previous workers:

A'. Late Sangamon or mid-Wisconsin (O'Sullivan 1966)

A. Wisconsin (Black 1964)

B. Sangamon (O'Sullivan 1966)

C. Mid-Pleistocene (O'Sullivan 1966)

D. Late Pliocene (O'Sullivan 1966)

Surfaces less than $8 \mathrm{~m}$ and 8 to $29 \mathrm{~m}$ in elevation are also shown.

A new delineation of this transgression is proposed, based largely on the inner limit of a $<8 \mathrm{~m}$ surface which some previous evidence suggests may have been the mid-Wisconsin, or prior, sea level high (Hopkins 1973). The use of elevation data for the positioning of this strand line assumes that there has been no subsequent uplift of the surface since the time of this transgression; however, this assumption is probably not true for the entire Coastal Plain. A comparison of this limit with previous limits is in general agreement except in the more westerly region of the Coastal Plain where the limits suggested by Black (1964) and O'Sullivan (1961) extend farther inland and westward. The 8-m limit appears to be more comparable to units mapped by lake morphology, although the $\mathrm{L}_{1}$ class (as mapped) does extend farther to the west than the boundary suggested by the $8-\mathrm{m}$ elevation. This evidence also suggests greater uplift in this area. 
The 29-m elevation also marks a topographic break on the Coastal Plain. In a restricted western part of the region this break may correspond to a pre-Illinoian strand line. If this line is carried across the Coastal Plain, whatever its age significance, it agrees with the transition between mapped lake units $\mathrm{L}_{3}$ and $\mathrm{L}_{4}$ in the central part of the area. In the western part of the Coastal Plain, the correlation of this limit with lake unit boundaries is not as good, which might be anticipated because of the range of geological and topographical conditions encountered. Therefore, the best correlation between mapped lake units and strand lines appears to be with the most recent transgression apparent on the existing land surface, as indicated by the $8-\mathrm{m}$ contour. The agreement would appear to improve by increasing the elevation by $3 \mathrm{~m}$ in the western section, although there is little basis for increasing the level by that amount.

\section{CONCLUSIONS}

The ERTS-1 imagery provides a regional view for classifying all of the lakes on the Alaskan Arctic Coastal Plain based on their size, shape, and orientation. This classification resulted in a grouping of the lakes into six lake units and three nonlake units. A means of estimating the depths of many lakes in this region appears possible based on the multispectral sequential ERTS-1 imagery. This technique relies on sequential imagery and observations of the persistence of ice cover during the thaw season. The lakes that retain an ice cover longest into the summer are the deepest. Three lake classes were developed based on this approach; $<1 \mathrm{~m}, 1-2 \mathrm{~m}$, and $>2 \mathrm{~m}$. The intermediate depth class depended on the contrast in the imagery between MSS bands 5 and 7. The band 5 imagery, with its greater potential for water penetration, made it possible to detect lakes that were frozen to the bottom and whose ice cover was flooded, only making them appear ice-free.

The potential maximum depth of thaw settlement, based on the volume of ground ice and thaw settlement in the Barrow area, indicated that conditions on this part of the Coastal Plain favored formation of lakes less than $2 \mathrm{~m}$ in depth and that lakes deeper than this should be limited in number.

The relationship between regional slope and lake size indicates the extremely low regional slope required for development of large thaw lakes. Most lakes occur at regional relief angles of less than $1^{\circ}$.

The percentage of land covered by lakes is not as large as one might judge from maps, photos, and aerial views. The contoured water-land percentages help to illustrate the regional controls of lake distribution. In addition to relief one of the more pronounced controls appears to be the location of major drainage networks, which tends to modify and control lake development and distribution.

The correlation of the various mapped lake classes with land surfaces of various ages is most obvious between the youngest seaward section of the area and the largest lake class. Additional correlation with the older surfaces is apparent in some areas and these can be correlated with both regional and local relief patterns unique to the various surfaces.

\section{SELECTED BIBLIOGRAPHY}

Black, R.F. (1964) Gubik formation of Quaternary age in northern Alaska. U.S. Geological Survey Professional Paper 302-C.

Black, R.F. (1969a) Thaw depressions and thaw lakes - a review. Biuletyn Peryglacjalny, vol. 19, p. 131-150.

Black, R.F. (1969b) Geology, especially geomorphology of northern Alaska. Arctic, vol. 22, p. 283-299. 
Black, R.F. and W.L. Barksdale (1949) Oriented lakes of northern Alaska. Journal of Geology, vol. 51, p. 105-118.

Brewer, M.C. (1958) The thermal regime of an arctic lake. Transactions of American Geophysical Union, vol. 39, p. 278-284.

Britton, M.E. (1967) Vegetation of the arctic tundra. In Arctic Biology (H.P. Hansen, Ed.), 18th Annual Biological Colloquium, Oregon State University, 2nd ed., p. 67-130.

Brown, J. (1965) Radiocarbon dating, Barrow, Alaska. Arctic, vol. 18, p. 36-48.

Brown, J. (1969) Ionic concentration gradients in permafrost, Barrow, Alaska. U.S. Army Cold Regions Research and Engineering Laboratory (USA CRREL) Research Report 272.

Brown, J. (1970) Environmental setting, Barrow, Alaska. In Proceedings of the Conference on Productivity and Conservation in Northern Circumpolar Lands, Section 3, (W. Fuller, Ed.), Morges, Switzerland, IUCN, p. 50-71.

Brown, J. and P.V. Sellmann (1973) Permafrost and coastal plain history of arctic Alaska. In Alaskan Arctic Tundra (Max E. Britton, Ed.), Arctic Institute of North America, Technical Paper no. 25, p. 31-47.

Carson, C.E. (1968) Radiocarbon dating of lacustrine strands in arctic Alaska. Arctic, vol. 21, p. $12-26$.

Carson, C.E. and K.M. Hussey (1962) The oriented lakes of arctic Alaska. Journal of Geology, vol. 70, p. 417-439.

Coyne, P.I. and J.J. Kelley (1974) Carbon dioxide partial pressures in arctic surface water. Limnology and Oceanography, vol. 19, p. 928-938.

Fischer, W.A. and E.H. Lathram (1973) Concealed structures in arctic Alaska identified on ERTS-1 imagery. Oil and Gas Journal, May 28, 1973.

Gatto, L.W. and D.M. Anderson (1975) Alaskan thermokarst terrain and possible Martian analogy. Science, vol. 188, p. 255-257.

Hopkins, D.M. (1973) Sea level history in Beringina during the past 250,000 years. Quaternary Research, vol. 3, p. 520- 540 .

Hussey, K.M. and R.W. Michelson (1966) Tundra relief features near Point Barrow, Alaska. Arctic, vol. 19, p. 162-184.

Lachenbruch, A.H., M.C. Brewer, G.W. Greene and B.V. Marshall (1962) Temperatures in permafrost. In Temperature, its Measurement and Control in Science and Industry, vol. 3, pt. 1, p. 791-803.

Lewellen, R.I. (1972) Studies on the fluvial environment, Arctic Coastal Plain Province, Northern Alaska. Published by the author, Littleton, Colorado.

Livingstone, D.A., K. Bryan, Jr. and R.G. Leahy (1958) Effects of an arctic environment on the origin and development of fresh-water lakes. Limnology and Oceanography, vol. 3, p. $192-214$.

Mackay, J.R. (1972) The world of underground ice. In Annual Association of American Geography, vol. 62, p. 1-22.

O'Sullivan, J.B. (1961) Quaternary geology of the Arctic Coastal Plain, Northern Alaska (unpublished). Ph.D. thesis, Iowa State University.

O’Sullivan, J.B. (1966) Geochemistry of permafrost, Barrow, Alaska. Permafrost International Conference, NAS-NRC Publ. no. 1287, p. 30-37.

Polcyn, F.C. and Lyzenga (1973) Updating coastal and navigational charts using ERTS-1 data. In Proceedings from Third Earth Resources Technology Satellite Symposium, 10-14 December, p. 1333-1346.

Sellmann, P.V. and J. Brown (1965) Coring of frozen ground, Barrow, Alaska. USA CRREL Special Report 81.

Sellmann, P.V. and J. Brown (1973) Stratigraphy and diagenesis of perennially frozen sediments in the Barrow, Alaska region. In Proceedings of the Second International Conference on Permafrost, NAS-NRC, p. 171-181.

Sellmann, P.V., W.F. Weeks and W.J. Campbell (1975) Use of side-looking airborne radar to determine lake depth in the Alaskan North Slope. USA CRREL Special Report 230.

Short, A.D. and L.D. Wright (1974) Lineaments and coastal geomorphic patterns in the Alaskan Arctic. Geological Society of America Bulletin, vol. 85, p. 931-936.

Ugolini, F.C. (1975) Ice-rafted sediments as a cause of some thermokarst lakes in the Noatak River delta, Alaska. Science, vol. 188, p. 51-53.

UNESCO (1970) Perennial ice and snow masses, a guide for compilation and assemblage of data for a world inventory. Paris: United Nations Educational, Scientific and Cultural Organization/International Association of Scientific Hydrology. 

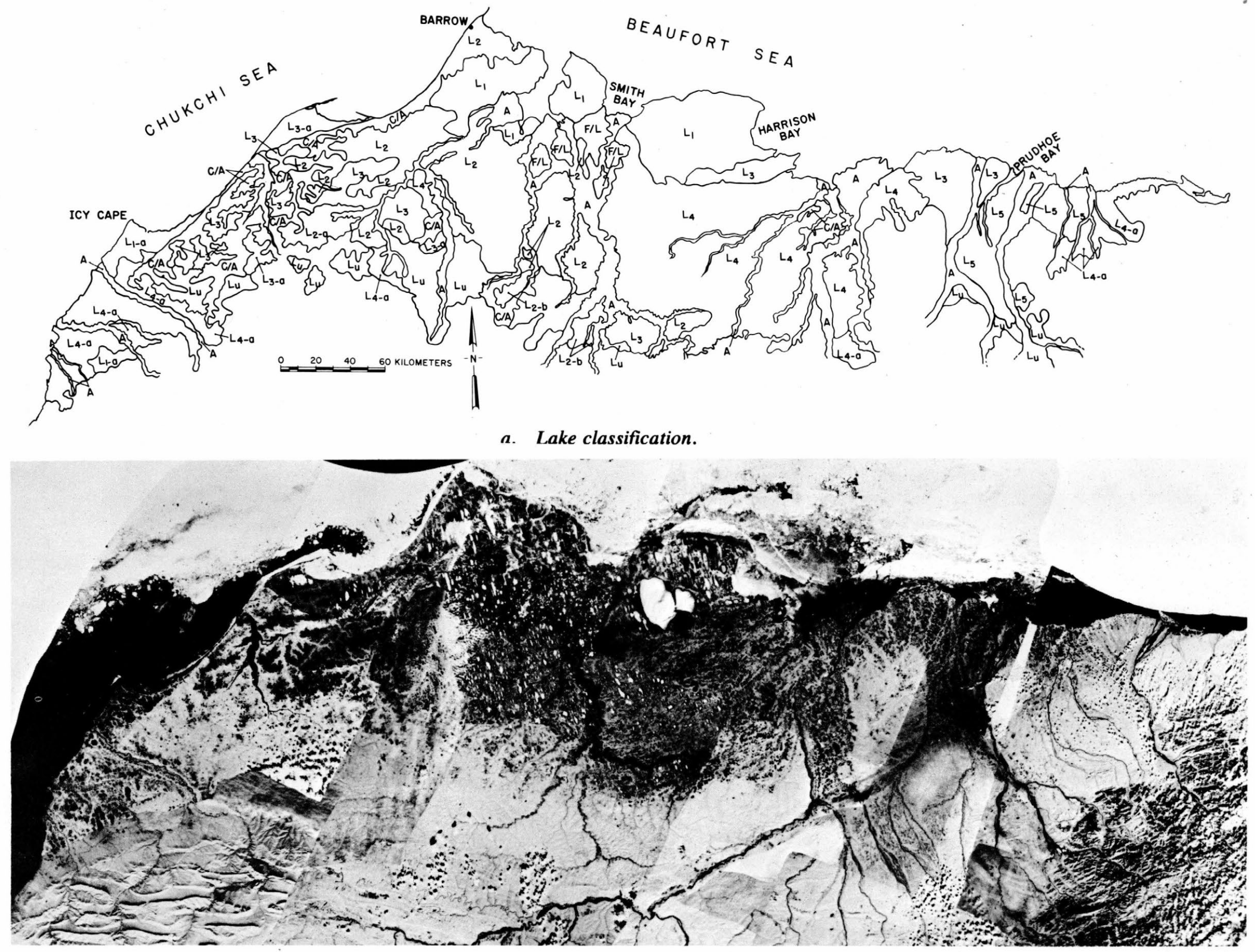

b. ERTS-1 uncontrolled mosaic (a composite of 1973 band 7, summer imagery).

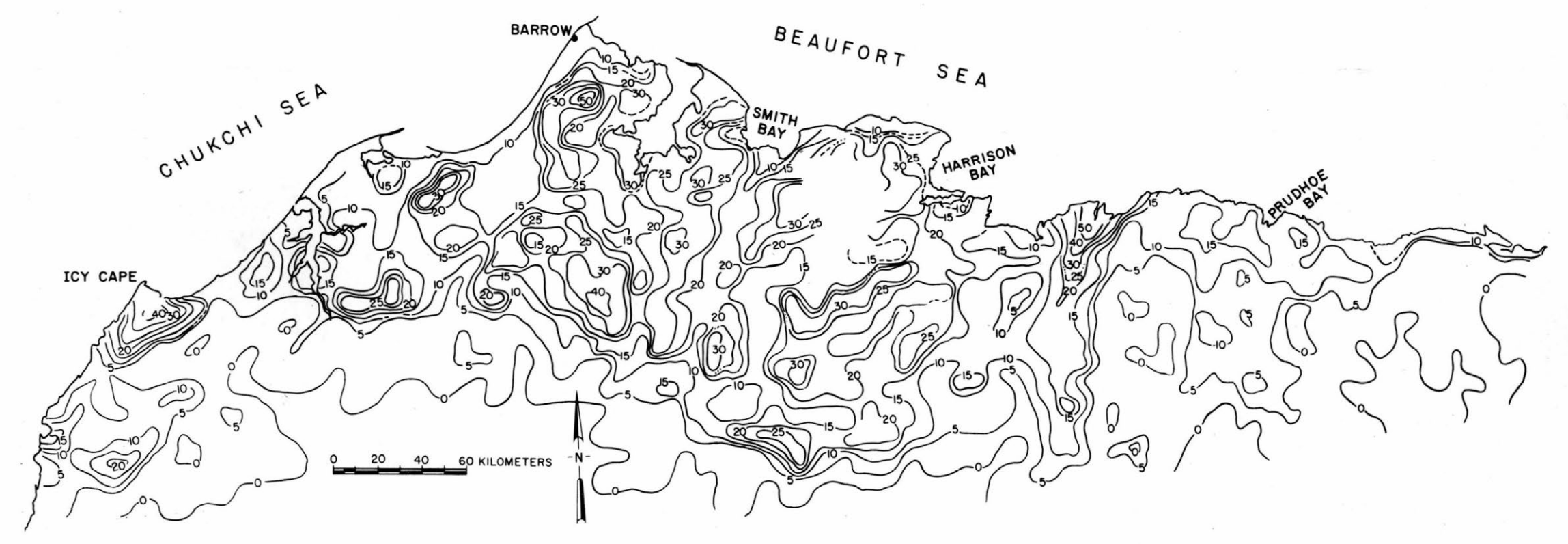

c. Contour of percentage land cover by water. 